\title{
Scientific Attitude of Scheduled Caste and Non-Scheduled Caste Adolescents in Relation to Home Environment
}

\author{
Ms. Manisha ${ }^{1 *}$
}

\section{ABSTRACT}

The Present investigation was to find out the relationship between scientific attitude and home environment of 200 scheduled caste and non-scheduled caste adolescents. Survey method of investigation was employed. The findings of the study showed that insignificant negative correlation was obtained between scientific attitude and home environment dimensions A, B, C, $\mathrm{E}, \mathrm{F}, \mathrm{G}, \mathrm{I}, \mathrm{J}$ and total home environment of scheduled caste adolescents. Also insignificant positive correlation was obtained between scientific attitude and home environment dimensions $\mathrm{D}$ and $\mathrm{H}$ of scheduled caste adolescents. Insignificant negative correlation was obtained between scientific attitude and home environment dimensions $\mathrm{A}$ and $\mathrm{F}$ of non-scheduled caste adolescents. Also insignificant positive correlation was obtained between scientific attitude and home environment dimensions B, C, D, E, G, H, I, J and total home environment of nonscheduled caste adolescents.

Keywords: Scientific Attitude, Home Environment, Adolescents

Right from the beginning a child acts with curiosity to know about living things and his interest in them is spontaneous and natural. No sound educational system can afford to ignore and neglect curiosities and interests of children in their environment. In the light of this fact, science education in schools can never be overlooked. Besides this, it should not be forgotten that the primary aim of science, apart from the satisfaction of intellectual curiosity is the survival and human welfare and to the very emergence of man from his animal behaviour than the knowledge of sciences.

Presently scientific literacy has become an educational necessity for the survival of the man in the $21^{\text {st }}$ century. Science must be accepted as a core school subject and it must be taught in an understandable fashion to all students. There are many issues which require our attention for their solution in a democratic society. Some of the major issues of current importance are: population growth, environmental problems, need of modern business and industries for

\footnotetext{
${ }^{1}$ Assist. Prof., S.S.G.D.C.O.E., Panchkula, Haryana, India

*Responding Author

(C) 2016 I Manisha; licensee IJIP. This is an Open Access Research distributed under the terms of the Creative Commons Attribution License (http://creativecommons.org/licenses/by/2.0), which permits unrestricted use, distribution, and reproduction in any Medium, provided the original work is properly cited.
} 


\section{Scientific Attitude of Scheduled Caste and Non-Scheduled Caste Adolescents in Relation to Home Environment}

scientifically literates in the increasingly technological society competing for world markets and development of scientific attitude among children.

Bhattacharya (1997) concluded that there was a significant relationship between each of the three domains of scientific attitude and academic achievement. All the three domains of the variable of scientific attitude contributed $67.50 \%$ of variance towards academic achievement, which may be considered as high contribution.

Thiagarajan and Vasanthi (2002) concluded that scientific attitude, being a facilitating for better achievement of the student will help for their placement in completion of studies.

Akubuiro and Joshua (2004) concluded that student's attitude towards science subject is a very important factor in achievement in science.

Yadav and Patel (1999) found that favourable home environment plays a significant role in developing creative abilities.

Peecook (2000) indicated that home educational support had a greater influence on academic achievement than teacher instructional practices in mathematics, science, and social science.

Basantia and Mukhopadhya (2001) found that in case of Indian rural school students, home environment emerged as a significant predictor of academic achievement as high achievement as high achievers, boys and girls, enjoyed better home environment.

\section{METHODOLOGY}

The present study is a survey type in nature. Here the data has been collected personally from the students. The method applied is of descriptive type. Purposive sampling method was used to select the schools.

\section{Sample}

A sample of $2009^{\text {th }}$ class adolescents (100 boys and 100 girls) was selected randomly from 10 government and government aided schools of Ludhiana district of Punjab state.

\section{Objectives}

1. To study the scientific attitude of scheduled caste $9^{\text {th }}$ class students.

2. To study the scientific attitude of non-scheduled caste $9^{\text {th }}$ class students.

3. To study the home environment of scheduled caste $9^{\text {th }}$ class students.

4. To study the home environment of non-scheduled caste $9^{\text {th }}$ class students.

\section{Hypotheses}

1. There exists a significant relationship between scientific attitude and home environment of scheduled caste $9^{\text {th }}$ class students 
2. There exists a significant relationship between scientific attitude and home environment of non-scheduled caste $9^{\text {th }}$ class students.

\section{Tools}

1. Scientific Attitude scale by Kaur (2002).

2. Home Environment Inventory by Mishra (1989).

\section{RESULTS AND DISCUSSIONS}

Table 1: showing values of coefficient of correlation between Scientific Attitude and dimensions of Home Environment, Total Home Environment of scheduled caste $9^{\text {th }}$ class students

\begin{tabular}{|l|l|l|}
\hline Sr. No. & Variable code & 'r' value \\
\hline & Home environment & \\
\hline 1. & Dimension A (control) & -0.107 \\
\hline 2. & Dimension B (protectiveness) & -0.043 \\
\hline 3. & Dimension C (punishment) & -0.094 \\
\hline 4. & Dimension D (conformity) & 0.055 \\
\hline 5. & Dimension E (social isolation) & -0.149 \\
\hline 6. & Dimension F (reward) & -0.014 \\
\hline 7. & Dimension G (deprivation of privileges) & -0.042 \\
\hline 8. & Dimension H (nurturance) & 0.117 \\
\hline 9. & Dimension I (rejection) & -0.082 \\
\hline 10. & Dimension J (permissiveness) & -0.008 \\
\hline 11. & Total home environment & -0.075 \\
\hline
\end{tabular}

Home environment dimensions A, B, C, E, F, G, I, J and home environment total were found to be insignificantly negatively correlated with scientific attitude of scheduled caste $9^{\text {th }}$ class students. The values of coefficient of correlation were $-0.107,-0.043,-0.094,-0.149,-0.014$, $0.042,-0.082,-0.008$ and -0.075 (vide table 1).Home environment dimensions $\mathrm{D}$ and $\mathrm{H}$ were found to be insignificantly positively correlated with scientific attitude of scheduled caste $9^{\text {th }}$ class students. The values of coefficient of correlation were 0.055 and 0.117 . Therefore, hypothesis no. 1 i.e. there exists a significant relationship between scientific attitude and home environment of scheduled caste $9^{\text {th }}$ class students was rejected. 
Table 2: showing values of coefficient of correlation between Scientific Attitude and dimensions of Home Environment, Total Home Environment of Non-scheduled caste $9^{\text {th }}$ class students $(N=100)$.

\begin{tabular}{|l|l|l|}
\hline Sr. No. & Variable code & 'r' value \\
\hline & Home environment & \\
\hline 1. & Dimension A (control) & -0.077 \\
\hline 2. & Dimension B (protectiveness) & 0.034 \\
\hline 3. & Dimension C (punishment) & 0.059 \\
\hline 4. & Dimension D (conformity) & 0.029 \\
\hline 5. & Dimension E (social isolation) & 0.073 \\
\hline 6. & Dimension F (reward) & -0.030 \\
\hline 7. & Dimension G (deprivation of privileges) & 0.020 \\
\hline 8. & Dimension H (nurturance) & 0.076 \\
\hline 9. & Dimension I (rejection) & 0.187 \\
\hline 10. & Dimension J (permissiveness) & 0.175 \\
\hline 11. & Total home environment & 0.134 \\
\hline
\end{tabular}

Home environment dimensions $\mathrm{A}$ and $\mathrm{F}$ were found to be insignificantly negatively correlated with scientific attitude of non-scheduled caste $9^{\text {th }}$ class students. The values of coefficient of correlation were -0.077 and -0.030 (vide table 2).Home environment dimensions $B, C, D, E, G$, $\mathrm{H}, \mathrm{I}, \mathrm{J}$ and home environment total were found to be insignificantly positively correlated with scientific attitude of non scheduled caste $9^{\text {th }}$ class students. The values of coefficient of correlation were $0.034,0.059,0.029,0.073,0.020,0.076,0.187,0.175$ and 0.134 . Therefore, hypothesis no. 2 i.e. there exits a significant relationship between scientific attitude and home environment of non-scheduled caste $9^{\text {th }}$ class students was rejected.

\section{CONCLUSIONS}

On the basis of the present study the following conclusions have been drawn:

1. There exists insignificant relationship between scientific attitude and home environment of scheduled caste $9^{\text {th }}$ class students

2. There exists insignificant relationship between scientific attitude and home environment of non-scheduled caste $9^{\text {th }}$ class students.

\section{EDUCATIONAL IMPLICATIONS}

This study has shown insignificant relationship between scientific attitude and home environment of scheduled caste and non-scheduled caste adolescents. It is therefore, the sole responsibility of the school to provide proper environment to the students for the development of the scientific attitude. The teachers should have scientific attitude in themselves. There should be proper arrangement for the experiment work in the school because it is the key factor in the development of the scientific attitude. Open mindedness should be encouraged in the students. 


\section{Scientific Attitude of Scheduled Caste and Non-Scheduled Caste Adolescents in Relation to Home Environment}

Also aversion to superstitions should be emphasized. Qualities like objectivity, loyalty to truth, critical and keen observation should be properly inculcated in the students as all these help in the development of scientific attitude. Thus there should be a good scientific environment in the school for the inculcation of the scientific attitude in the students which is the foremost need in today's world.

\section{Acknowledgement}

With my sincerity, I bow before almighty for his benevolence and blessings. I also offer my sincere thanks to my parents, husband, sister and Son for their cooperation and moral support during the course of this research. I am equally grateful to the teachers and heads of the various institutions, who ungrudgingly rendered all help and cooperation in the collection of the data. I am also thankful to the Editor in Chief and Publishing team of the journal without whose support the paper could not get the present status.

\section{REFERENCES}

Akuburio, I.M. and Joshua, M. T. (2004). Self Concept, Attitude and Achievement of Secondary Schools Students in Southern Cross River State Nigeria. The African Symposium, Vol. 4. No. 1, 32-34.

Baharudin, R. \& Luster, T. (1998). Factors related to the Quality of the Home Environment and Children's Achievement. Journal of Family issues, 19 (4), 370-375.

Basantia, J.M. \& Mukhopadhaya, D. (2001). Effect of Environmental Factors on AchievementA study on rural students. The Educational Review, 44 (11), 21-24.

Best, J.W. (1959). Research in Education. U.S.A. Prentice Hall Inc.

Bhattacharya, G.C. (1997). Scientific Attitude and Its Relationship With Academic Achievement in Higher Secondary Level. School Science, Vol. XXXV (3), 68-71.

Chaudhary, M. \& Kaur, P. (1993). Impact of Home Environment on Moral Values of Children. Prachi journal of psycho cultural Dimension, Vol. 9 (1), 39-43.

Coleman, A. M. (2001). Dictionary of Psychology. Oxford University Press, New Delhi.

Coleman, J.C. (1973). Psychology and Effective Behaviour. D.B. Taraporevala Sons and Co. Pvt. Ltd, New Delhi.

Dinkmeyer, D.C. (1967). Child Development. Prentice Hall of India Pvt. Ltd., New Delhi. Jerslid, A.t. (1968). Educational Psychology, Prentice Hall of India Pvt. Ltd., New Delhi.

Kaur, A. (2002). A Study of Select Intellectual and Non Intellectual Correlates of Scientific Attitude. Ph.D. Thesis., Panjab University, Chandigarh.

Lata, K. \& Aggarwal (1998). Effect of absence of Maternal Encouragement and its Impact on Educational Development of adolescents. The progress of Education, vol. LXIII (4), 2731.

Peecook, E.V. (2000), The Effect of Home Environmental Support and Teacher Instructional Practices on Secondary School Students' Academic Achievement and Perceptions of Content Meaningfulness. Dissertation Abstracts International, 61(4), 67-70. 
Sambrani, M.R. (1997). Home Environment and Emotional Disturbance among Adolescents. Indian Psychological Review. Vol. 48 (4), 11-14.

Thiagarajan, A.P. and Vasanthi, A. (2002). Scientific Attitude of the Prospective Science Teachers in The Colleges of Education. Journal of Educational Research and Extension, Vol. 39 (3), 23-26.

Yadav, R.S. \& Patel, H.L. (1999). International Effect of Home Environment and Locality on creativity. Journal of All India Association of Educational Research. Vol. 11 (3), 31-38.

How to cite this article: Manisha (2016), Scientific Attitude of Scheduled Caste and NonScheduled Caste Adolescents in Relation to Home Environment, International Journal of Indian Psychology, Volume 3, Issue 3, No. 9, DIP: 18.01.158/20160303, ISBN: 978-1-365-13820-1 